\title{
Review Article \\ Toxicity and Bioremediation of Heavy Metals Contaminated Ecosystem from Tannery Wastewater: A Review
}

\author{
Bernard E. Igiri $\left(\mathbb{D},{ }^{1}\right.$ Stanley I. R. Okoduwa, ${ }^{1,2}$ Grace O. Idoko, ${ }^{1}$ Ebere P. Akabuogu, \\ Abraham O. Adeyi, ${ }^{1}$ and Ibe K. Ejiogu ${ }^{1}$ \\ ${ }^{1}$ Chemical and Biochemical Remediation Unit, Directorate of Research and Development, Nigerian Institute of Leather and \\ Science Technology, Zaria 810001, Kaduna State, Nigeria \\ ${ }^{2}$ Infohealth Awareness Department, SIRONigeria Global Limited, Abuja 900001, FCT, Nigeria \\ Correspondence should be addressed to Bernard E. Igiri; egwubernard2@gmail.com
}

Received 2 May 2018; Revised 17 July 2018; Accepted 16 August 2018; Published 27 September 2018

Academic Editor: Valerio Matozzo

Copyright (c) 2018 Bernard E. Igiri et al. This is an open access article distributed under the Creative Commons Attribution License, which permits unrestricted use, distribution, and reproduction in any medium, provided the original work is properly cited.

\begin{abstract}
The discharge of untreated tannery wastewater containing biotoxic substances of heavy metals in the ecosystem is one of the most important environmental and health challenges in our society. Hence, there is a growing need for the development of novel, efficient, eco-friendly, and cost-effective approach for the remediation of inorganic metals $(\mathrm{Cr}, \mathrm{Hg}, \mathrm{Cd}$, and $\mathrm{Pb})$ released into the environment and to safeguard the ecosystem. In this regard, recent advances in microbes-base heavy metal have propelled bioremediation as a prospective alternative to conventional techniques. Heavy metals are nonbiodegradable and could be toxic to microbes. Several microorganisms have evolved to develop detoxification mechanisms to counter the toxic effects of these inorganic metals. This present review offers a critical evaluation of bioremediation capacity of microorganisms, especially in the context of environmental protection. Furthermore, this article discussed the biosorption capacity with respect to the use of bacteria, fungi, biofilm, algae, genetically engineered microbes, and immobilized microbial cell for the removal of heavy metals. The use of biofilm has showed synergetic effects with many fold increase in the removal of heavy metals as sustainable environmental technology in the near future.
\end{abstract}

\section{Introduction}

Industrial tannery wastewater is a major source of heavy metal contamination in our environment. Heavy metals are of economic significance in industrial use and the most important pollutants in the environment. Environmental pollution by heavy metals has become a serious threat to living organisms in an ecosystem [1-5]. Metal toxicity is of great environmental concern because of their bioaccumulation and nonbiodegradability in nature $[6,7]$. Several inorganic metals like magnesium $(\mathrm{Mg})$, nickel $(\mathrm{Ni})$, chromium $\left(\mathrm{Cr}^{3+}\right)$, copper $(\mathrm{Cu})$, calcium $(\mathrm{Ca})$, manganese $(\mathrm{Mn})$, and sodium $(\mathrm{Na})$ as well as zinc $(\mathrm{Zn})$ are vital elements needed in small quantity for metabolic and redox functions. Heavy metals such as aluminium $(\mathrm{Al})$, lead $(\mathrm{Pb})$, cadmium $(\mathrm{Cd})$, gold $(\mathrm{Au})$, mercury $(\mathrm{Hg})$, and silver $(\mathrm{Ag})$ do not have any biological role and are toxic to living organisms $[1,8,9]$.
Bioremediation is employed in order to transform toxic heavy metals into a less harmful state using microbes [10-12] or its enzymes to clean-up polluted environment [13]. The technique is environmentally friendly and costeffective in the revitalization of the environment $[3,9,14]$. Bioremediation of heavy metals has limitations. Among these are production of toxic metabolites by microbes and nonbiodegradability of heavy metals.

The direct use of microorganisms with distinctive features of catabolic potential and/or their products such as enzymes and bio surfactant is a novel approach to enhance and boost their remediation efficacy $[15,16]$. Different alternatives have also been anticipated to widen the applications of microbiological techniques towards the remediation of heavy metals. For instance, the use of microbial fuel cell (MFC) to degrade recalcitrant heavy metals has been explored. Biofilmmediated bioremediation can be applied for cleaning up of heavy metal contaminated environment. 
Microbial technologies are active and growing [17]. Long trajectory exists on how microbes and metals interact in both natural and man-made environments. Microbial-metal interactions is primarily focused on metals removal, i.e., remediation and depollution. The recent revival of the use of solid-state electrodes as electron donors or acceptors for microbial growth has brought innovative prospects, resulting to microbial-electrochemical technologies (METs) [18]. The application of microorganisms as a green approach for the synthesis of metallic nanoparticles (NPs) has been reported [19]. Genetically modified microorganisms have also been used as a remediation technique [20, 21]. Genetic engineering and chemical modification could alter the components of cells surface and can efficiently improve the adsorption capacity and selectivity to target-metal species.

Several factors which influences and limit bioremediation efficiency include temperature, $\mathrm{pH}$, redox potential, nutritional status, moisture, and chemical composition of heavy metals [22]. The use of microbes alone has shown limited efficiency owing to various factors including poor competitiveness as well as excessive heavy metal concentrations. Effectiveness can be enhanced by several amendments with inorganic nutrients, biosurfactants, bulking agents, and compost as well as biochar [23]. These adjustments have been comprehensively reviewed in recent studies [2426].

There are several protection mechanisms of heavy metal resistance by microbial cells. These mechanisms are extracellular barrier, extracellular sequestration, and active transport of metal ions (efflux), intracellular sequestration, and reduction of metal ions $[27,28]$.

This study therefore seeks to review the reports of previous investigators on the toxic effect and the use of microbial cell and their products, namely, biosurfactants, to enhance remediation of heavy metals. It also discusses the factors that influence bioremediation of heavy metals along with their underlining mechanisms. The findings and analyses are presented in the following sections. Current research work on microbial biosorption and detoxification is not only summarized but also future directions are suggested.

\section{Research Methodology}

2.1. Search Strategy. Relevant scientific literatures from major databases were searched for original research articles on the toxic effects of heavy metals and the use of microbial cell to remediate heavy metals. The following databases were searched: PubMed, ScienceDirect, and Google Scholar. The keyword combinations for the search were toxicity of heavy metals, tannery effluent, and biofilms, factors that affect microbial remediation, bioremediation, and mechanisms of microbial remediation.

2.2. Inclusion Criteria. Original scientific research studies that reported on the toxic effects of heavy metals and the use of microorganisms to clean up heavy metal in the ecosystem were included.
2.3. Exclusion Criteria. Articles that reported on the bioremediation of organic compounds, phytoremediation of heavy metals, and other biological techniques were excluded.

\section{Toxicity of Heavy Metals to Microorganisms}

Toxicity of heavy metals is the ability of a metal to cause detrimental effects on microorganisms, and it depends on the bioavailability of heavy metal and the absorbed dose [29]. Heavy metal toxicity involves several mechanisms, that is, breaking fatal enzymatic functions, reacting as redox catalysts in the production of reactive oxygen species (ROS), destructing ion regulation, and directly affecting the formation of DNA as well as protein $[30,31]$. The physiological and biochemical properties of microorganisms can be altered by the presence of heavy metals. Chromium (Cr) and cadmium $(\mathrm{Cd})$ are capable of inducing oxidative damage and denaturation of microorganisms as well as weakening the bioremediation capacity of microbes.

Chromium Cr (III) may change the structure and activity of enzymes by reacting with their carboxyl and thiol groups [32]. Intracellular cationic Cr (III) complexes interact electrostatically with negatively charged phosphate groups of DNA, which could affect transcription, replication, and cause mutagenesis [32].

Heavy metals like copper ( $\mathrm{Cu}(\mathrm{I})$ and $\mathrm{Cu}(\mathrm{II})$ ) could catalyse the production of ROS via Fenton and Haber-Weis reactions, which will act as soluble electron carries. This can cause severe injury to cytoplasmic molecules, DNA, lipids, and other proteins $[33,34]$. Aluminium (Al) could stabilize superoxide radicals, which is responsible for DNA damage [35]. Heavy metals could stop vital enzymatic functions by competitive or noncompetitive interactions with substrates that will cause configurational changes in enzymes [30]. Furthermore, it can also cause ion imbalance by adhering to the cell surface and entering through ion channels or transmembrane carriers [36].

Cadmium $(\mathrm{Cd})$ and lead $(\mathrm{Pb})$ pose deleterious effect on microbes, damage cell membranes, and destroy the structure of DNA. This harmfulness is generated by the displacement of metals from their native binding sites or ligand interactions [37]. The morphology, metabolism, and growth of microbes are affected by changing the nucleic acid structure, causing functional disturbance, disrupting cell membranes, inhibiting enzyme activity, and oxidative phosphorylation $[38,39]$ (Table 1).

\section{Factors Affecting Microbial Remediation of Heavy Metals}

The propensity of heavy metals to be stimulatory or inhibitory to microorganisms is determined by the total metal ion concentrations, chemical forms of the metals, and related factors such as redox potential. Environmental factors like temperature, $\mathrm{pH}$, low molecular weight organic acids, and humic acids can alter the transformation, transportation, valance state of heavy metals, and the bioavailability of heavy metals towards microorganisms. Heavy metals tend to form free ionic species at acidic $\mathrm{pH}$ levels, with more protons 
TABLE 1: Toxicity of heavy metals to microorganisms.

\begin{tabular}{lcc}
\hline Heavy Metals & Effects on Microbes & Citations \\
\hline Arsenic & Deactivation of enzymes & {$[40]$} \\
Cadmium & Denature protein, destroy nucleic acid, hinder cell division and transcription & {$[38]$} \\
Chromium & Growth inhibition, elongation of lag phase, inhibition of oxygen uptake & {$[32]$} \\
Copper & Disrupt cellular function, inhibit enzyme activities & {$[38]$} \\
Selenium & Inhibits growth rate & {$[41]$} \\
Lead & Destroyed nucleic acid and protein, inhibit enzyme actions and transcription \\
Mercury & Denature protein, inhibit enzyme function, disrupt cell membrane & {$[38]$} \\
Nickel & Upset cell membrane, hinder enzyme activities and oxidative stress & \\
Silver & Cell lysis, inhibit cell transduction and growth & {$[38,42]$} \\
Zinc & Death, decrease in biomass, inhibits growth & {$[43]$} \\
\hline
\end{tabular}

available to saturate metal-binding sites. At higher hydrogen ion concentrations, the adsorbent surface is more positively charged, hence reducing the attraction between adsorbent and metal cations thereby increasing its toxicity.

Temperature plays a significant role in the adsorption of heavy metals. Increase in temperature increases the rate of adsorbate diffusion across the external boundary layer. The solubility of heavy metals increases with an increase in temperature, which improves the bioavailability of heavy metals [44]. However, the actions of microorganisms increase with rise in temperature at a suitable range, and it enhances microbial metabolism and enzyme activity, which will accelerate bioremediation. The stability of microbesmetal complex depends on the sorption sites, microbial cell wall configuration, and ionization of chemical moieties on the cell wall. The outcome of degradation process depends on the substrate and range of environmental factors (Table 2).

\section{Mechanism of Microbial Detoxification of Heavy Metal}

Microorganisms adopt different mechanisms to interact and survive in the presence of inorganic metals. Various mechanisms used by microbes to survive metal toxicity are biotransformation, extrusion, use of enzymes, production of exopolysaccharide (EPS) [41, 46], and synthesis of metallothioneins. In response to metals in the environment, microorganisms have developed ingenious mechanisms of metal resistance and detoxification. The mechanism involves several procedures, together with electrostatic interaction, ion exchange, precipitation, redox process, and surface complexation [47]. The major mechanical means to resist heavy metals by microorganism are metal oxidation, methylation, enzymatic decrease, metal-organic complexion, metal decrease, metal ligand degradation, metal efflux pumps, demethylation, intracellular and extracellular metal sequestration, exclusion by permeability barrier, and production of metal chelators like metallothioneins and bio surfactants [48].

Microorganisms can decontaminate metals by valence conversion, volatilization, or extracellular chemical precipitation [48]. Microorganisms have negative charge on their cell surface because of the presence of anionic structures that empower the microbes to bind to metal cations [49]. The

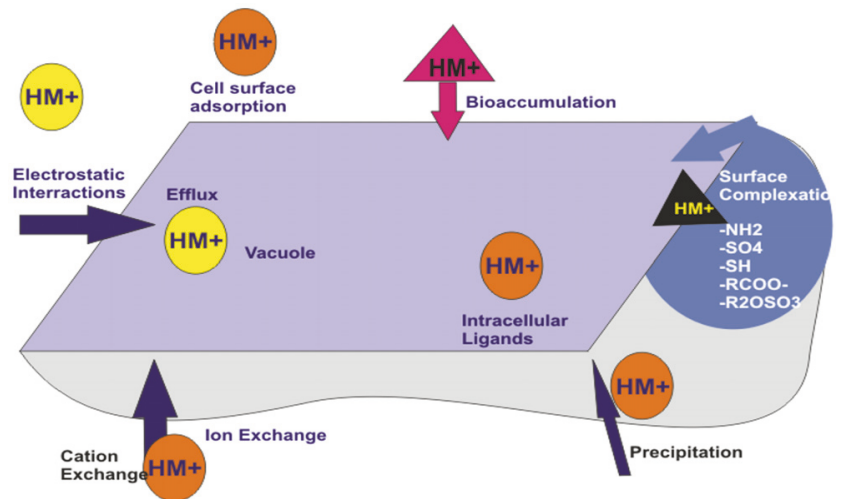

FIgURE 1: Mechanisms of heavy metal uptake by microorganisms $[47,53]$.

negatively charged sites of microbes involved in adsorption of metal are the hydroxyl, alcohol, phosphoryl, amine, carboxyl, ester, sulfhydryl, sulfonate, thioether, and thiol groups [49].

5.1. Bio Sorption Mechanism. The uptake of heavy metals by microbial cells through biosorption mechanisms can be classified into metabolism-independent biosorption, which mostly occurs on the cells exterior and metabolism-dependent bioaccumulation, which comprises sequestration, redox reaction, and species-transformation methods [50, 51]. Bio sorption can be carried out by dead biomass or living cells as passive uptake through surface complexation onto the cell wall and surface layers [52]. Bioaccumulation depends on a variety of chemical, physical, and biological mechanisms (Figure 1) and these factors are intracellular and extracellular processes, where biosorption plays a limited and ill-defined role [52].

5.2. Intracellular Sequestration. Intracellular sequestration is the complexation of metal ions by various compounds in the cell cytoplasm. The concentration of metals within microbial cells can result from interaction with surface ligands followed by slow transport into the cell. The ability of bacterial cells to accumulate metals intracellular has been exploited in practices, predominantly in the treatment of effluent treatment. Cadmium-tolerant $P$. putida strain possessed the ability of 
TABLE 2: Factors that influence bioremediation of heavy metals [45].

\begin{tabular}{|c|c|}
\hline Factors & Activities \\
\hline \multirow{4}{*}{ Microbial } & (i) Production of toxic metabolites \\
\hline & (ii) Enzymes induction \\
\hline & (iii) Mutation and horizontal gene transfer \\
\hline & (iv) Enrichment of capable microbial populations \\
\hline \multirow{4}{*}{ Substrate } & (i) Chemical structure of contaminants \\
\hline & (ii) Too low concentration of contaminants \\
\hline & (iii) Toxicity of contaminants \\
\hline & (iv) Solubility of contaminants \\
\hline \multirow{3}{*}{ Environmental } & (i) Inhibitory Environmental conditions \\
\hline & (ii) Depletion of preferential substrates \\
\hline & (iii) Lack of nutrients \\
\hline \multirow{3}{*}{ Mass transfer limitations } & (i) Oxygen diffusion and solubility \\
\hline & (ii) Solubility/miscibility in/with water \\
\hline & (iii) Diffusion of nutrients \\
\hline \multirow{3}{*}{ Growth substrate vs. co-metabolism } & (i) Microbial interaction( competition, succession, and predation) \\
\hline & (ii) Concentration \\
\hline & (iii) Alternate carbon source present \\
\hline \multirow{3}{*}{ Biological aerobic vs. anaerobic process } & (i) Microbial population present in the site \\
\hline & (ii) Oxidation/reduction potential \\
\hline & (iii) Availability of electron acceptors \\
\hline
\end{tabular}

intracellular sequestration of copper, cadmium, and zinc ions with the help of cysteine-rich low molecular weight proteins [54]. Also, intracellular sequestration of cadmium ions by glutathione was revealed in Rhizobium leguminosarum cells [55].

The rigid cell wall of fungi is made up of chitin, mineral ions, lipids, nitrogen-containing polysaccharide, polyphosphates, and proteins. They can decontaminate metal ions by energetic uptake, extracellular and intracellular precipitation, and valence conversion, with several fungi accumulating metals to their mycelium and spores. The exterior of the cell wall of fungi behaves like a ligand used for labelling metal ions and brings about the elimination of inorganic metals [56-59]. Peptidoglycan, polysaccharide, and lipid are components of cell wall that are rich in metal-binding ligands (e.g., - $\mathrm{OH}$, $\mathrm{COOH},-\mathrm{HPO} 42-$, SO42- - RCOO-, R2OSO3-, -NH2, and -SH). Amine can be more active in metal uptake among these functional groups, as it binds to anionic metal species via electrostatic interaction and cationic metal species through surface complexation.

5.3. Extracellular Sequestration. Extracellular sequestration is the accumulation of metal ions by cellular components in the periplasm or complexation of metal ions as insoluble compounds. Copper-resistant Pseudomonas syringae strains produced copper-inducible proteins CopA, CopB (periplasmic proteins), and CopC (outer membrane protein) which bind copper ions and microbial colonies [60]. Bacteria can eject metal ions from the cytoplasm to sequester the metal within the periplasm. Zinc ions can cross from the cytoplasm by efflux system where they are accumulated in the periplasm of Synechocystis PCC 6803 strain [61].

Metal precipitation is an extracellular sequestration. Iron reducing bacterium such as Geobacter spp. and sulfur reducing bacterium like Desulfuromonas spp. are capable of reducing harmful metals to less or nontoxic metals. G. metallireducens, a strict anaerobe, is capable of reducing manganese (Mn), from lethal $\mathrm{Mn}$ (IV) to $\mathrm{Mn}$ (II), and uranium (U), from poisonous U (VI) to U (IV) [49]. G. sulfurreducens and $G$. metallireducens have the ability to decrease chromium (Cr) from the very lethal $\mathrm{Cr}$ (VI) to less toxic $\mathrm{Cr}$ (III) [62]. Sulfate-reducing bacteria generate large amounts of hydrogen sulfide that causes precipitation of metal cations $[63,64]$.

Klebsiella planticola strain generates hydrogen sulfide from thiosulfate under anaerobic conditions and precipitated cadmium ions as insoluble sulfides [65]. Also, cadmium was precipitated by $P$. aeruginosa strain under aerobic conditions [66]. Vibrio harveyi strain precipitated soluble divalent lead as complex lead phosphate salt [67].

5.4. Extracellular Barrier of Preventing Metal Entry into Microbial Cell. Microbial plasma membrane, cell wall, or capsule could prevent metal ions from entering the cell. Bacteria can adsorb metal ions by ionizable groups of the cell wall (amino, carboxyl, phosphate, and hydroxyl groups) [68, 69]. Pardo et al. [70], Taniguchi et al. [69], and Green-Ruiz [71] observed high level of passive biosorption of heavy metal ions for nonviable cells of Pseudomonas putida, Brevibacterium sp., and Bacillus sp. 
Pseudomonas aeruginosa biofilm cells show higher resistance to ions of copper, lead, and zinc than planktonic cells, while cells located at the periphery of the biofilm were killed. Extracellular polymers of biofilm accumulated metal ions and then protect bacterial cells inside the biofilm [72].

5.5. Methylation of Metals. Methylation increases metal toxicity as a result of increased lipophilicity and thus increased permeation across cell membranes. Microbial methylation plays a significant function in metal remediation. Methylated compounds are regularly explosive; for instance, $\mathrm{Hg}$ (II) can be bio methylated by some bacteria such as Bacillus spp., Escherichia spp., Clostridium spp., and Pseudomonas spp. to gaseous methyl mercury. Bio methylation of selenium (Se) to volatile dimethyl selenide and arsenic (As) to gaseous arsines as well as lead $(\mathrm{Pb})$ to dimethyl lead was witnessed in polluted top soil [48].

5.6. Reduction of Heavy Metal Ions by Microbial Cell. Microbial cells can convert metal ion from one oxidation state to another, hence reducing their harmfulness [73]. Bacteria use metals and metalloids as electron donors or acceptors for energy generation. Metals in the oxidized form could serve as terminal acceptors of electrons during anaerobic respiration of bacteria. Reduction of metal ions through enzymatic activity could result in formation of less toxic form of mercury and chromium $[74,75]$.

\section{Bioremediation Capacity of Microorganisms on Heavy Metals}

The uptake of heavy metals by microorganisms occurs via bioaccumulation which is an active process and/or through adsorption, which is a passive process. Several microorganisms like bacteria, fungi, and algae have been used to clean up heavy metal contaminated environments (Table 3) [76, 77]. The application of metal-resistant strains in single, consortium, and immobilized form for the remediation of heavy metals has yielded effective results while the immobilized form could have more chemosorption sites to biosorb heavy metals.

6.1. Bacteria Remediation Capacity of Heavy Metal. Microbial biomass has different biosorptive abilities, which also varies significantly among microbes. However, the biosorption ability of each microbial cell depends on its pretreatment and the experimental conditions. Microbial cell must adapt to alteration of physical, chemical and bioreactor configuration to enhance biosorption [52]. Bacteria are important biosorbents due to their ubiquity, size, and ability to grow under controlled conditions and resilience to environmental conditions $[78,79]$.

De Jaysankar and his coauthors [99] use mercuryresistant bacteria such as Alcaligenes faecalis, Bacillus pumilus, Pseudomonas aeruginosa, and Brevibacterium iodinium for the removal of cadmium $(\mathrm{Cd})$ and lead $(\mathrm{Pb})$. In this study, $P$. aeruginosa and $A$. faecalis removed $70 \%$ and $75 \%$ cadmium (Cd) with reduction of $1000 \mathrm{mg} / \mathrm{L}$ to $17.4 \mathrm{mg} / \mathrm{L}$ of cadmium (Cd) by $P$. aeruginosa and to $19.2 \mathrm{mg} / \mathrm{L}$ by $A$. faecalis in about
$72 \mathrm{hrs}$. Brevibacterium iodinium and Bacillus pumilus remove greater than $87 \%$ and $88 \%$ of lead $(\mathrm{Pb})$ with a reduction of $1000 \mathrm{mg} / \mathrm{L}$ to $1.8 \mathrm{mg} / \mathrm{L}$ in 96 hours (Table 3). In another study, [118] uses indigenous facultative anaerobic Bacillus cereus to detoxify hexavalent chromium. Bacillus cereus has an excellent capacity of $72 \% \mathrm{Cr}(\mathrm{VI})$ removal at $1000 \mu \mathrm{g} / \mathrm{mL}$ chromate concentration. The bacteria were capable of reducing $\mathrm{Cr}(\mathrm{VI})$ under a wide range of temperatures $\left(25\right.$ to $\left.40^{\circ} \mathrm{C}\right)$ and $\mathrm{pH}(6$ to 10) with optimum at $37^{\circ} \mathrm{C}$ and initial $\mathrm{pH} 8.0$.

Several heavy metals have been tested using bacteria species like Flavobacterium, Pseudomonas, Enterobacter, Bacillus, and Micrococcus sp. (Table 3). Their great biosorption ability is due to high surface-to-volume ratios and the potential active chemosorption sites (teichoic acid) on the cell wall [119]. Bacteria are more stable and survive better when they are in mixed culture [120]. Therefore, consortia of cultures are metabolically superior for biosorption of metals and are more appropriate for field application [121]. De Jaysankar et al. [99] reported $78 \%$ reduction of chromium (Cr) using bacteria consortium of Acinetobacter sp. and Arthrobacter sp. of $16 \mathrm{mg} / \mathrm{L}$ metal ion concentration. Micrococcus luteus was used to remove a huge quantity of $\mathrm{Pb}$ from a synthetic medium. Under ideal environments, the elimination ability was $1965 \mathrm{mg} / \mathrm{g}$ [122].

Abioye and his coworkers [123] investigated the biosorption of lead $(\mathrm{Pb})$, chromium $(\mathrm{Cr})$, and cadmium $(\mathrm{Cd})$ in tannery effluent using Bacillus subtilis, B. megaterium, Aspergillus niger, and Penicillium sp. B. megaterium recorded the highest lead $(\mathrm{Pb})$ reduction $(2.13$ to $0.03 \mathrm{mg} / \mathrm{L})$, followed by $B$. subtilis $(2.13-0.04 \mathrm{mg} / \mathrm{L})$. A. niger show the highest ability to reduce the concentration of chromium $(\mathrm{Cr})(1.38$ $0.08 \mathrm{mg} / \mathrm{L})$ followed by Penicillium sp. $(1.38-0.13 \mathrm{mg} / \mathrm{L})$ while $B$. subtilis exhibited the highest ability to reduce the concentration of cadmium $(\mathrm{Cd})(0.4-0.03 \mathrm{mg} / \mathrm{L})$ followed by $B$. megaterium (0.04-0.06 mg/L) after 20 days. Kim and his coauthors [76], designed a batch system using zeoliteimmobilized Desulfovibrio desulfuricans for the removal of chromium $\left(\mathrm{Cr}^{6+}\right)$, copper $(\mathrm{Cu})$, and nickel $(\mathrm{Ni})$ with removal efficiency of $99.8 \%, 98.2 \%$, and $90.1 \%$, respectively ( Table 3 ). Ashruta and his coworkers [124] reported efficient removal of chromium, zinc, cadmium, lead, copper, and cobalt by bacterial consortia at approximately 75 to $85 \%$ in less than two hours of contact duration.

6.2. Fungi Remediation Capacity of Heavy Metal. Fungi are widely used as biosorbents for the removal of toxic metals with excellent capacities for metal uptake and recovery [125127]. Most studies showed that active and lifeless fungal cells play a significant role in the adhesion of inorganic chemicals [111, 128-130]. Srivastava and Thakur [131] also reported the efficiency of Aspergillus sp. used for the removal of chromium in tannery waste water. $85 \%$ of chromium was removed at $\mathrm{pH} 6$ in a bioreactor system from the synthetic medium, compared to a $65 \%$ removal from the tannery effluent. This could be due to the presence of organic pollutants that hinder the growth of the organism.

Coprinopsis atramentaria is studied for its ability to bioaccumulate $76 \%$ of $\mathrm{Cd}^{2+}$, at a concentration of $1 \mathrm{mg} \mathrm{L}-1$ of $\mathrm{Cd}^{2+}$, and $94.7 \%$ of $\mathrm{Pb}^{2+}$, at a concentration of $800 \mathrm{mg} \mathrm{L}-1$ 


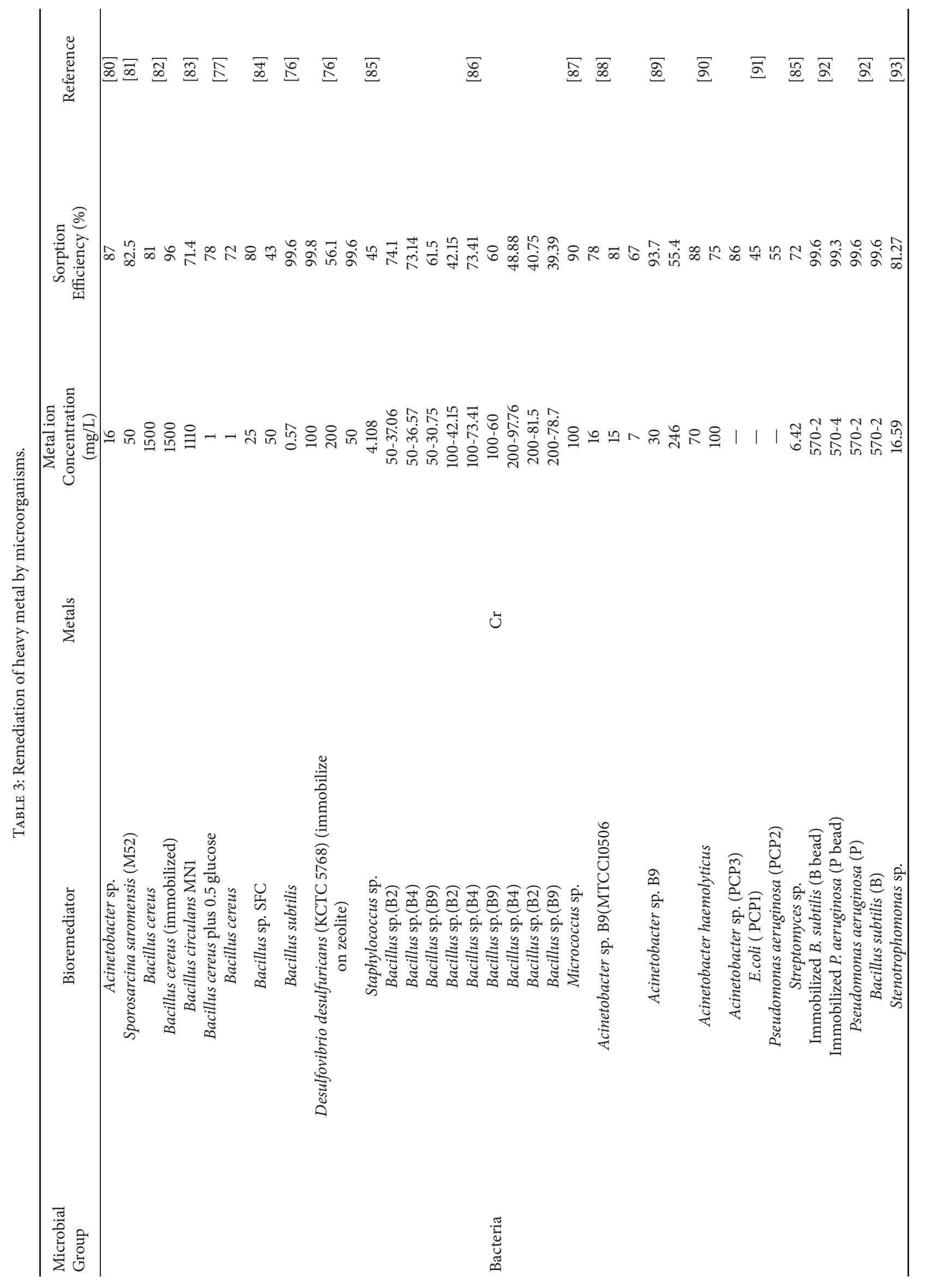




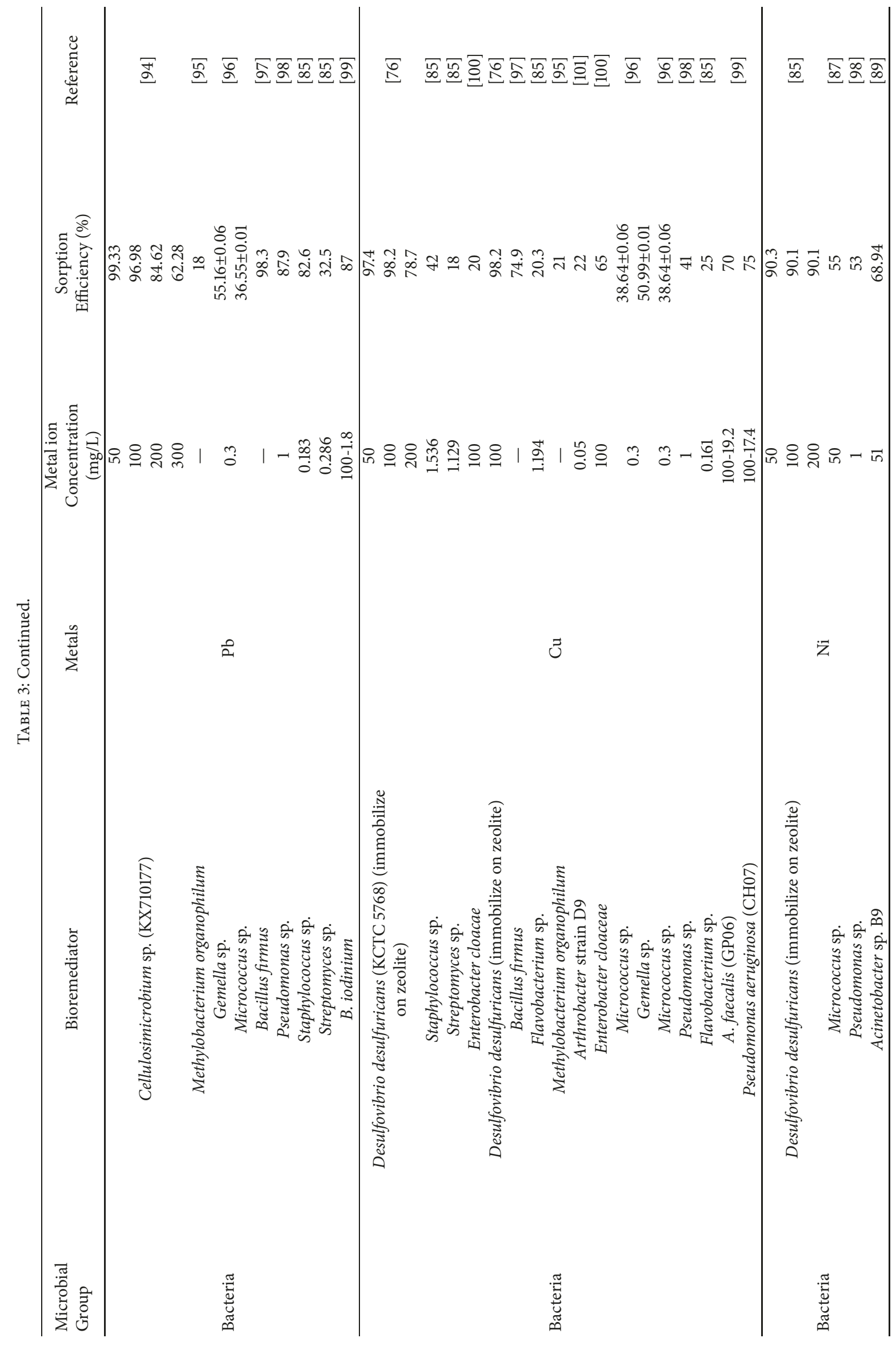




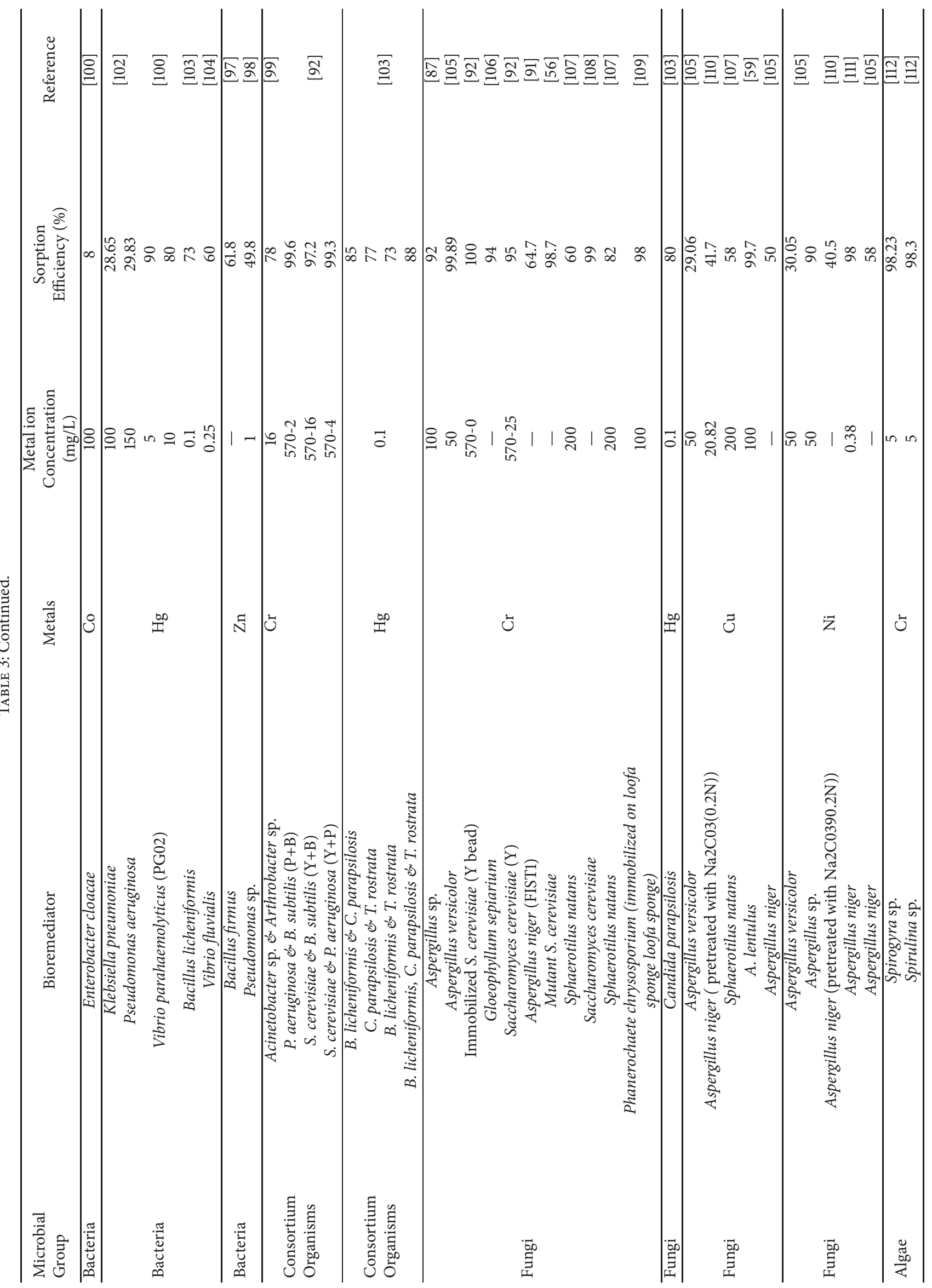




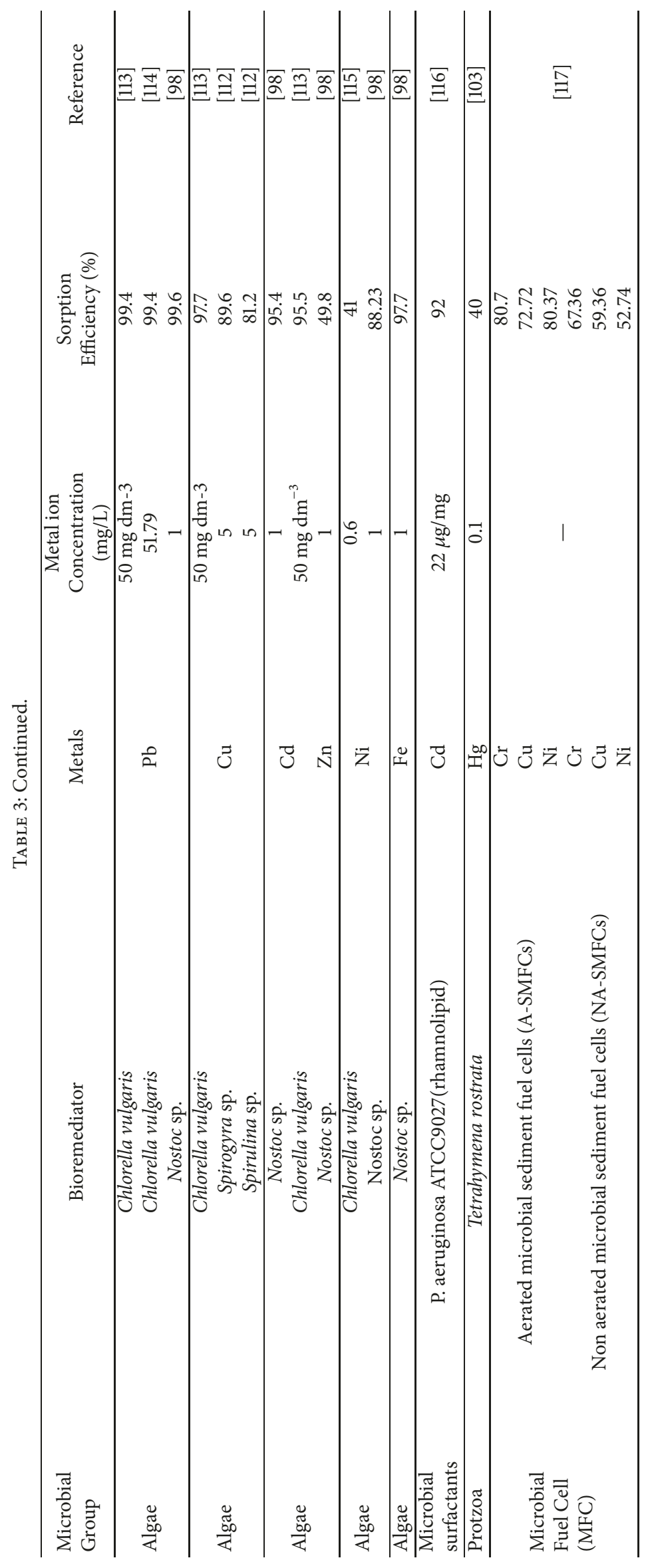


of $\mathrm{Pb}^{2+}$. Therefore, it has been documented as an effective accumulator of heavy metal ions for mycoremediation [132]. Park and his coauthors [133] reported that dead fungal biomass of Aspergillus niger, Rhizopus oryzae, Saccharomyces cerevisiae, and Penicillium chrysogenum could be used to convert toxic Cr (VI) to less toxic or nontoxic Cr (III). Luna et al. [134] also observed that Candida sphaerica produces biosurfactants with a removal efficiency of $95 \%, 90 \%$, and $79 \%$ for $\mathrm{Fe}$ (iron), zinc $(\mathrm{Zn})$, and lead $(\mathrm{Pb})$, respectively. These surfactants could form complexes with metal ions and interact directly with heavy metals before detachment from the soil. Candida spp. accumulate substantial quantity of nickel $\mathrm{Ni}(57-71 \%)$ and copper $\mathrm{Cu}(52-68 \%)$, but the process was affected by initial metal ion concentration and $\mathrm{pH}$ (optimum 3-5) [135].

Biosurfactants have gained interest in recent years owing to their low toxicity, biodegradable nature, and diversity. Mulligan et al. [136] assessed the viability of using surfactin, rhamnolipid, and sophorolipid for the removal of heavy metals $(\mathrm{Cu}$ and $\mathrm{Zn}$ ). A single washing with $0.5 \%$ rhamnolipid removed $65 \%$ of copper $(\mathrm{Cu})$ and $18 \%$ of the zinc $(\mathrm{Zn})$, whereas $4 \%$ sophorolipid removed $25 \%$ of the copper $(\mathrm{Cu})$ and $60 \%$ of zinc $(\mathrm{Zn})$. Several strains of yeast such as Hansenula polymorpha, S. cerevisiae, Yarrowia lipolytica, Rhodotorula pilimanae, Pichia guilliermondii, and Rhodotorula mucilage have been used to bio-convert Cr (VI) to $\mathrm{Cr}$ (III) [137-139].

6.3. Heavy Metal Removal Using Biofilm. There are several reports on the application of biofilms for the removal of heavy metals. Biofilm acts as a proficient bioremediation tool as well as biological stabilization agent. Biofilms have very high tolerance against toxic inorganic elements even at a concentration that is lethal. It was revealed in a study conducted on Rhodotorula mucilaginosa that metal removal efficiency was from 4.79 to $10.25 \%$ for planktonic cells and from 91.71 to $95.39 \%$ for biofilm cells [140]. Biofilms mechanisms of bioremediation could either be via biosorbent or by exopolymeric substances present in biofilms which contain molecules with surfactant or emulsifier properties [141].

6.4. Algae Remediation Capacity of Heavy Metal. Algae are autotrophic and hence require low nutrients and produce enormous biomass compared to other microbial biosorbents. These biosorbents have also been used for heavy metal removal with a high sorption capacity [12]. Algae biomass is used for bioremediation of heavy metal polluted effluent via adsorption or by integration into the cells. Phycoremediation is the use of various types of algae and cyanobacteria for the remediation of heavy metals by either removal or degradation of toxicant [142]. Algae have various chemical moieties on their surface such as hydroxyl, carboxyl, phosphate, and amide, which act as metal-binding sites $[12,143]$.

Goher and his coauthors [113] used dead cells of Chlorella vulgaris to remove cadmium $\left(\mathrm{Cd}^{2+}\right)$, copper $\left(\mathrm{Cu}^{2+}\right)$, and lead $\left(\mathrm{Pb}^{2+}\right)$ ions from aqueous solution under various conditions of $\mathrm{pH}$, biosorbent dosage, and contact time. The results suggested that the biomass of $C$. vulgaris is an extremely efficient biosorbent for the removal of cadmium $\left(\mathrm{Cd}^{2+}\right)$, copper $\left(\mathrm{Cu}^{2+}\right)$ and lead $\left(\mathrm{Pb}^{2+}\right)$ at $95.5 \%, 97.7 \%$, and 99.4 $\%$, respectively, from mixed solution of $50 \mathrm{mg} \mathrm{dm}^{-3}$ of each metal ion (Table 3).

6.5. Immobilized Biosorption of Heavy Metal. The use of encapsulated biomass enhances biosorption performance and increases its physical and chemical stability. Immobilizations of microbial biomass in polymeric matrixes confer rigidity and heat resistivity with optimum porosity for practical applications. Agrobacterium biomass was encapsulated in alginate with iron oxide nanoparticles and showed an adsorption capacity of $197.02 \mathrm{mg} / \mathrm{g}$ for $\mathrm{Pb}$ and was effective for five consecutive cycles [144].

6.6. Microbial Genetic Engineering. With the advanced in genetic engineering, microbes are engineered with desired characteristics such as ability to tolerate metal stress, overexpression of metal-chelating proteins and peptides, and ability of metal accumulation. Frederick et al. [145] engineered microorganisms to produce trehalose and establish that it reduces $1 \mathrm{mM} \mathrm{Cr}$ (VI) to $\mathrm{Cr}$ (III). Engineered Chlamydomonas reinhardtii generated significant increase in tolerance to Cd toxicity and its accumulation [146]. Genetically engineered microbes for heavy metal remediation involve the use of Escherichia coli (E. coli ArsR (ELP153AR)) to target As(III) [147] and Saccharomyces cerevisiae (CP2 HP3) to target $\mathrm{Cd}^{2+}$ and $\mathrm{Zn}^{2+}$ [148]. Corynebacterium glutamicum was genetically modified using overexpression of ars operons (ars1 and ars2) to decontaminate As-contaminated sites [149].

Bioremediation of heavy metals has been extensively studied and the performance of several bioremediators were reviewed and summarized. Bioremediation is an environmentally friendly and cost-effective technology for the cleanup of complex industrial tannery effluent containing heavy metals. Many natural biosorbents of microbial origins have been identified with efficient biosorption characteristics. Recent surface modifications on these bioremediators have helped to ameliorate their metal-binding properties and increase the overall cost of the process. In spite of such short comings, both native and modified biosorbents have demonstrated their compatibility when tested with tannery effluent. These biosorbents showed effective metal removal over a wide range of temperature, $\mathrm{pH}$, and solution conditions.

\section{Future Outlook}

Certain factors inhibiting the widespread application of this technology as identified by various researchers include difficulty in obtaining a reliable and inexpensive biomass and negative effects of coexisting metal ions on biosorptive capacity among others. Tannery effluent and biosorbent characteristics need to be assessed prior to application. Keeping in focus the inhibitions of bioremediation technology, the future prospect looks promising on microbial genetic technologies and the development of increased specificity using biofilms which could be achieved by optimization process and immobilization techniques. Hence, more effort should be made in biofilms mediated bioremediation, genetically 
modified microbes, and microbial fuel cell (MFC) in the bioremediation of heavy metals in the ecosystem.

\section{Conclusion}

The current states of the bioremediation of heavy metal reviewed in this study show much promise for metal biosorption and detoxification, especially from biofilm and genetically modified microbes. Biofilm-mediated techniques, microbial gene transfer, and microbial fuel cells-based techniques have come up as strong contenders in recent years. The peptidoglycan and polysaccharides component of the cell wall of the biosorbents is an active binding site for higher metal uptake. This technique is cost-effective and a green technology that has advantages such as faster kinetics, high metal binding over a broad range of $\mathrm{pH}$, and temperature. This review provides an opportunity to reveal the role of microbial cell, biofilm, and their metabolites towards remediation of heavy metals and environmental research. Further research area needs to be extended on the focus of gene transfer within biofilms for heavy metal remediation. These would facilitate the development of improved techniques for the bioremediation of heavy metals in the ecosystem.

\section{Conflicts of Interest}

The authors declared that there are no conflicts of interest regarding the publication of this paper.

\section{Authors' Contributions}

This study was conducted in collaboration between all the authors. Bernard E. Igiri got the concept of the study, wrote the manuscript draft, and participated in the revision. Stanley I. R. Okoduwa designed the study and critically revised the manuscript for important intellectual content. Grace O. Idoko, Abraham O. Adeyi, Ebere P. Akabuogu, and Ibe $\mathrm{K}$. Ejiogu participated in the acquisition and management of relevant literatures for manuscript draft and subsequent revision. The final version was written by Bernard E. Igiri and Stanley I. R. Okoduwa. All authors gave a final approval of the revised version to be published.

\section{Acknowledgments}

The authors are grateful to members and coresearch scholars of the Directorate of Research and Development, Nigerian Institute of Leather and Science Technology, Zaria-Nigeria, for their moral support during the course of this project.

\section{References}

[1] S. Siddiquee, K. Rovina, and S. A. Azad, "Heavy metal contaminants removal from wastewater using the potential filamentous fungi biomass: a review," Journal of Microbial and Biochemical Technology, vol. 07, no. 06, pp. 384-393, 2015.

[2] C. Su, "A review on heavy metal contamination in the soil worldwide: Situation, impact and remediation techniques," Environmental Skepticsand Critics, vol. 3, pp. 24-38, 2014.
[3] K. Hrynkiewicz and C. Baum, "Application of microorganisms in bioremediation of environment from heavy metals," Environmental Deterioration and Human Health: Natural and Anthropogenic Determinants, pp. 215-227, 2014.

[4] N. C. Deepa and S. Suresha, "Biosorption of lead (II) from aqueous solution and industrial effluent by using leaves of araucaria cookii: application of response surface methodology," IOSR Journal of Environmental Science, Toxicology and Food Technology, vol. 8, no. 7, pp. 67-79, 2014.

[5] V. N. Okolo, E. A. Olowolafe, I. Akawu, and S. I. R. Okoduwa, "Effects of industrial effluents 581 on soil resource in challawa industrial area," Journal of Global Ecology and Environment, vol. 5, no. 1, p. 10, 2016.

[6] R. K. Gautam, S. Soni, and M. C. Chattopadhyaya, "Functionalized magnetic nanoparticles for environmental remediation," Handbook of Research on Diverse Applications of Nanotechnology in Biomedicine, Chemistry, and Engineering, pp. 518-551, 2014.

[7] W. L. Wai, N. A. K. Kyaw, and N. H. N. Nway, "Biosorption of Lead $(\mathrm{Pb} 2+)$ by using Chlorella vulgaris," in Proceedings of the International Conference on Chemical engineering and its applications (ICCEA), Bangkok (Thailand), 2012.

[8] D. Lakherwal, "Adsorption of heavy metals: a review," International Journal of Environmental Research Development, vol. 4, pp. 41-48, 2014.

[9] R. Turpeinen, T. Kairesalo, and M. Haggblom, "Microbial activity community structure in arsenic, chromium and copper contaminated soils," Journal of Environmental Microbiology, vol. 35, no. 6, pp. 998-1002, 2002.

[10] R. J. Ndeddy Aka and O. O. Babalola, "Effect of bacterial inoculation of strains of pseudomonas aeruginosa, alcaligenes feacalis and bacillus subtilis on germination, growth and heavy metal (Cd, Cr, and $\mathrm{Ni}$ ) uptake of brassica juncea," International Journal of Phytoremediation, vol. 18, no. 2, pp. 200-209, 2016.

[11] A. Akcil, C. Erust, S. Ozdemiroglu, V. Fonti, and F. Beolchini, "A review of approaches and techniques used in aquatic contaminated sediments: metal removal and stabilization by chemical and biotechnological processes," Journal of Cleaner Production, vol. 86, pp. 24-26, 2015.

[12] H. S. Abbas, M. I. Ismail, M. T. Mostafa, and H. A. Sulaymon, "Biosorption of heavy metals: A review," Journal of Chemical Science and Technology, vol. 3, pp. 74-102, 2014.

[13] S. I. R. Okoduwa, B. Igiri, C. B. Udeh, C. Edenta, and B. Gauje, "Tannery effluent treatment by yeast species isolates from watermelon," Toxics, vol. 5, no. 1, p. 6, 2017.

[14] Y. Ma, M. Rajkumar, C. Zhang, and H. Freitas, "Beneficial role of bacterial endophytes in heavy metal phytoremediation," Journal of Environmental Management, vol. 174, pp. 14-25, 2016.

[15] T. T. Le, M.-H. Son, I.-H. Nam, H. Yoon, Y.-G. Kang, and Y.-S. Chang, "Transformation of hexabromocyclododecane in contaminated soil in association with microbial diversity," Journal of Hazardous Materials, vol. 325, pp. 82-89, 2017.

[16] P. M. Schenk, L. C. Carvalhais, and K. Kazan, "Unraveling plantmicrobe interactions: Can multi-species transcriptomics help?" Trends in Biotechnology, vol. 30, no. 3, pp. 177-184, 2012.

[17] T. Hennebel, N. Boon, S. Maes, and M. Lenz, "Biotechnologies for critical raw material recovery from primary and secondary sources: R\&D priorities and future perspectives," New Biotechnology, vol. 32, no. 1, pp. 121-127, 2015.

[18] J. C. Thrash and J. D. Coates, "Review: Direct and indirect electrical stimulation of microbial metabolism," Environmental Science \& Technology, vol. 42, no. 11, pp. 3921-3931, 2008. 
[19] T. Klaus-Joerger, R. Joerger, E. Olsson, and C. Granqvist, "Bacteria as workers in the living factory: metal-accumulating bacteria and their potential for materials science," Trends in Biotechnology, vol. 19, no. 1, pp. 15-20, 2001.

[20] I. Poirier, P. Hammann, L. Kuhn, and M. Bertrand, "Strategies developed by the marine bacterium Pseudomonas fluorescens BA3SM1 to resist metals: A proteome analysis," Aquatic Toxicology, vol. 128, pp. 215-232, 2013.

[21] V. Paliwal, S. Puranik, and H. J. Purohit, "Integrated perspective for effective bioremediation," Applied Biochemistry and Biotechnology, vol. 166, no. 4, pp. 903-924, 2012.

[22] P. K. Shukla, S. Sharma, K. N. Singh, V. Singh, S. Bisht, and V. Kumar, Rhizoremediation: A Promising Rhizosphere Technology, Y. B. Patil and P. Rao, Eds., vol. 331, 2013.

[23] A. Wiszniewska, E. Hanus-Fajerska, E. MuszyŃska, and K. Ciarkowska, "Natural organic amendments for improved phytoremediation of polluted soils: a review of recent progress," Pedosphere, vol. 26, no. 1, pp. 1-12, 2016.

[24] M. Kästner and A. Miltner, "Application of compost for effective bioremediation of organic contaminants and pollutants in soil," Applied Microbiology and Biotechnology, vol. 100, no. 8, pp. 3433-3449, 2016.

[25] B. Lukić, D. Huguenot, A. Panico, M. Fabbricino, E. D. van Hullebusch, and G. Esposito, "Importance of organic amendment characteristics on bioremediation of PAH-contaminated soil," Environmental Science and Pollution Research, vol. 23, no. 15, pp. 15041-15052, 2016.

[26] J. Truu, M. Truu, M. Espenberg, H. Nõlvak, and J. Juhanson, "Phytoremediation and plant-assisted bioremediation in soil and treatment wetlands: A review," Open Biotechnology Journal, vol. 9, no. 1, pp. 85-92, 2015.

[27] R. Choudhury and S. Srivastava, "Zinc resistance mechanisms in bacteria," Current Science, vol. 81, no. 7, pp. 768-775, 2001.

[28] M. R. Bruins, S. Kapil, and F. W. Oehme, "Microbial resistance to metals in the environment," Ecotoxicology and Environmental Safety, vol. 45, no. 3, pp. 198-207, 2000.

[29] L. D. Rasmussen, S. J. Sørensen, R. R. Turner, and T. Barkay, "Application of a mer-lux biosensor for estimating bioavailable mercury in soil," Soil Biology \& Biochemistry, vol. 32, no. 5, pp. 639-646, 2000.

[30] P. T. Gauthier, W. P. Norwood, E. E. Prepas, and G. G. Pyle, "Metal-PAH mixtures in the aquatic environment: A review of co-toxic mechanisms leading to more-than-additive outcomes," Aquatic Toxicology, vol. 154, pp. 253-269, 2014.

[31] U. Hildebrandt, M. Regvar, and H. Bothe, "Arbuscular mycorrhiza and heavy metal tolerance," Phytochemistry, vol. 68, no. 1, pp. 139-146, 2007.

[32] C. Cervantes, J. Campos-García, S. Devars et al., "Interactions of chromium with microorganisms and plants," FEMS Microbiology Reviews, vol. 25, no. 3, pp. 335-347, 2001.

[33] J. Giner-Lamia, L. López-Maury, F. J. Florencio, and P. J. Janssen, "Global transcriptional profiles of the copper responses in the cyanobacterium synechocystis sp. PCC 6803," PLoS ONE, vol. 9, no. 9, p. e108912, 2014.

[34] D. Osman and J. S. Cavet, "Copper Homeostasis in Bacteria," Advances in Applied Microbiology, vol. 65, pp. 217-247, 2008.

[35] S. C. Booth, A. M. Weljie, and R. J. Turner, "Metabolomics reveals differences of metal toxicity in cultures of Pseudomonas pseudoalcaligenes KF707 grown on different carbon sources," Frontiers in Microbiology, vol. 6, p. 827, 2015.
[36] S. Chen, H. Yin, J. Ye et al., "Influence of co-existed benzo[a]pyrene and copper on the cellular characteristics of Stenotrophomonas maltophilia during biodegradation and transformation," Bioresource Technology, vol. 158, pp. 181-187, 2014.

[37] A. O. Olaniran, A. Balgobind, and B. Pillay, "Bioavailability of heavy metals in soil: Impact on microbial biodegradation of organic compounds and possible improvement strategies," International Journal of Molecular Sciences, vol. 14, no. 5, pp. 10197-10228, 2013.

[38] M. O. Fashola, V. M. Ngole-Jeme, and O. O. Babalola, "Heavy metal pollution from gold mines: Environmental effects and bacterial strategies for resistance," International Journal of Environmental Research and Public Health, vol. 13, no. 11, p. 1047, 2016.

[39] M. Bissen and F. H. Frimmel, "Arsenic-a review. Part I: occurrence, toxicity, speciation, mobility," Acta Hydrochimica et Hydrobiologica, vol. 31, no. 1, pp. 9-18, 2003.

[40] M. Sankarammal, A. Thatheyus, and D. Ramya, "Bioremoval Of Cadmium Using Pseudomonas fluorescens," Open Journal of Water Pollution and Treatment, vol. 2014, no. 2, pp. 92-100, 2014.

[41] R. Dixit, Wasiullah, D. Malaviya et al., "Bioremediation of heavy metals from soil and aquatic environment: an overview of principles and criteria of fundamental processes," Sustainability , vol. 7, no. 2, pp. 2189-2212, 2015.

[42] A. Malik, "Metal bioremediation through growing cells," Environment International, vol. 30, no. 2, pp. 261-278, 2004.

[43] S. Prabhu and E. K. Poulose, "Silver nanoparticles: mechanism of antimicrobial action, synthesis, medical applications, and toxicity effects," International Nano Letters, vol. 2, no. 1, article no. 32, pp. 1-10, 2012.

[44] B. A. M. Bandowe, M. Bigalke, L. Boamah, E. Nyarko, F. K. Saalia, and W. Wilcke, "Polycyclic aromatic compounds (PAHs and oxygenated PAHs) and trace metals in fish species from Ghana (West Africa): Bioaccumulation and health risk assessment," Environment International, vol. 65, pp. 135-146, 2014.

[45] R. Boopathy, "Factors limiting bioremediation technologies," Bioresource Technology, vol. 74, no. 1, pp. 63-67, 2000.

[46] G. Wu, H. Kang, X. Zhang, H. Shao, L. Chu, and C. Ruan, "A critical review on the bio-removal of hazardous heavy metals from contaminated soils: Issues, progress, eco-environmental concerns and opportunities," Journal of Hazardous Materials, vol. 174, no. 1-3, pp. 1-8, 2010.

[47] T. Yang, M. Chen, and J. Wang, "Genetic and chemical modification of cells for selective separation and analysis of heavy metals of biological or environmental significance," TrAC Trends in Analytical Chemistry, vol. 66, pp. 90-102, 2015.

[48] K. Ramasamy, S. Kamaludeen, and B. Parwin, "Bioremediation of metals microbial processes and techniques," in Environmental Bioremediation Technologies, S. N. Singh and R. D. Tripathi, Eds., pp. 173-187, Springer Publication, New York, NY, USA, 2006.

[49] M. Gavrilescu, "Removal of heavy metals from the environment by biosorption," Engineering in Life Sciences, vol. 4, no. 3, pp. 219-232, 2004.

[50] K. Vijayaraghavan and Y.-S. Yun, "Bacterial biosorbents and biosorption," Biotechnology Advances, vol. 26, no. 3, pp. 266-291, 2008.

[51] B. Godlewska-Zyłkiewicz, "Microorganisms in inorganic chemical analysis," Analytical and Bioanalytical Chemistry, vol. 384, no. 1, pp. 114-123, 2006. 
[52] M. Fomina and G. M. Gadd, "Biosorption: current perspectives on concept, definition and application," Bioresource Technology, vol. 160, pp. 3-14, 2014.

[53] A. S. Ayangbenro and O. O. Babalola, "A new strategy for heavy metal polluted environments: A review of microbial biosorbents," International Journal of Environmental Research and Public Health, vol. 14, no. 94, 2017.

[54] D. P. Higham, P. J. Sadler, and M. D. Scawen, "Cadmium-binding proteins in pseudomonas putida: Pseudothioneins," Environmental Health Perspectives, vol. 65, pp. 5-11, 1986.

[55] A. I. G. Lima, S. C. Corticeiro, and E. M. de Almeida Paula Figueira, "Glutathione-mediated cadmium sequestration in Rhizobium leguminosarum," Enzyme and Microbial Technology, vol. 39, no. 4, pp. 763-769, 2006.

[56] Y. Xie, J. Fan, W. Zhu et al., "Effect of heavy metals pollution on soil microbial diversity and bermudagrass genetic variation," Frontiers in Plant Science, vol. 7, p. 775, 2016.

[57] V. K. Gupta, A. Nayak, and S. Agarwal, "Bioadsorbents for remediation of heavy metals: Current status and their future prospects," Environmental Engineering Research, vol. 20, no. 1, pp. 1-18, 2015.

[58] K. Selvam, B. Arungandhi, B. Vishnupriya, T. Shanmugapriya, and M. Yamuna, "Biosorption of chromium (vi) from industrial effluent by wild and mutant type strain of saccharomycescerevisiae and its immobilized form," Bioscience Discovery, vol. 4, no. 1, pp. 72-77, 2013.

[59] S. Jha, S. Dikshit, and G. Pandy, "Comparative study of agitation rate and stationary phase for the removal of cu2+ by A. lentulus," International Journal of Pharmacy and Biological Science, vol. 2, pp. 208-211, 2011.

[60] J.-S. Cha and D. A. Cooksey, "Copper resistance in Pseudomonas syringae mediated by periplasmic and outer membrane proteins," Proceedings of the National Acadamy of Sciences of the United States of America, vol. 88, no. 20, pp. 8915-8919, 1991.

[61] C. Thelwell, N. J. Robinson, and J. S. Turner-Cavet, "An SmtBlike repressor from Synechocystis PCC 6803 regulates a zinc exporter," Proceedings of the National Acadamy of Sciences of the United States of America, vol. 95, no. 18, pp. 10728-10733, 1998.

[62] M. Bruschi and G. Florence, "New bioremediation technologies to remove heavy metals and radionuclides using $\mathrm{Fe}(\mathrm{III})$-, sulfate-and sulfur-reducing bacteria," in Environmental Bioremediation Technologies, S. N. Singh and R. D. Tripathi, Eds., pp. 35-55, 2006.

[63] A. Luptakova and M. Kusnierova, "Bioremediation of acid mine drainage contaminated by SRB," Hydrometallurgy, vol. 77, no. 12, pp. 97-102, 2005.

[64] V. E. White and C. J. Knowles, "Effect of metal complexion on the bioavailability of nitriloacetic acid to Chelatobacter heintzil ATCC 2900," Achives of Microbiology, vol. 173, no. 5-6, pp. 373$382,2000$.

[65] P. K. Sharma, D. L. Balkwill, A. Frenkel, and M. A. Vairavamurthy, "A new Klebsiella planticola strain (Cd-1) grows anaerobically at high cadmium concentrations and precipitates cadmium sulfide," Applied and Environmental Microbiology, vol. 66, no. 7, pp. 3083-3087, 2000.

[66] C. L. Wang, S. C. Ozuna, D. S. Clark, and J. D. Keasling, "A deep-sea hydrothermal vent isolate, Pseudomonas aeruginosa CW961, requires thiosulfate for $\mathrm{Cd} 2+$ tolerance and precipitation," Biotechnology Letters, vol. 24, no. 8, pp. 637-641, 2002.

[67] C. E. Mire, J. A. Tourjee, W. F. O’Brien, K. V. Ramanujachary, and G. B. Hecht, "Lead precipitation by Vibrio harveyi : evidence for novel quorum-sensing interactions," Applied and Environmental Microbiology, vol. 70, no. 2, pp. 855-864, 2004.

[68] E. R. El-Helow, S. A. Sabry, and R. M. Amer, "Cadmium biosorption by a cadmium resistant strain of Bacillus thuringiensis: Regulation and optimization of cell surface affinity for metal cations," BioMetals, vol. 13, no. 4, pp. 273-280, 2000.

[69] J. Taniguchi, H. Hemmi, K. Tanahashi, N. Amano, T. Nakayama, and T. Nishino, "Zinc biosorption by a zinc-resistant bacterium, Brevibacterium sp. strain HZM-1," Applied Microbiology and Biotechnology, vol. 54, no. 4, pp. 581-588, 2000.

[70] R. Pardo, M. Herguedas, E. Barrado, and M. Vega, "Biosorption of cadmium, copper, lead and zinc by inactive biomass of Pseudomonas putida," Analytical and Bioanalytical Chemistry, vol. 376, no. 1, pp. 26-32, 2003.

[71] C. Green-Ruiz, "Mercury(II) removal from aqueous solutions by nonviable Bacillus sp. from a tropical estuary," Bioresource Technology, vol. 97, no. 15, pp. 1907-1911, 2006.

[72] G. M. Teitzel and M. R. Parsek, "Heavy metal resistance of biofilm and planktonic Pseudomonas aeruginosa," Applied and Environmental Microbiology, vol. 69, no. 4, pp. 2313-2320, 2003.

[73] B. Jyoti and K. S. N. Harsh, "Utilizing Aspergillus niger for bioremediation of tannery effluent," Octa Journal of Environmental Research, vol. 2, no. 1, pp. 77-81, 2014.

[74] T. Barkay, S. M. Miller, and A. O. Summers, "Bacterial mercury resistance from atoms to ecosystems," FEMS Microbiology Reviews, vol. 27, no. 2-3, pp. 355-384, 2003.

[75] C. Viti, A. Pace, and L. Giovannetti, "Characterization of $\mathrm{Cr}(\mathrm{VI})$-resistant bacteria isolated from chromium-contaminated soil by tannery activity," Current Microbiology, vol. 46, no. 1, pp. 1-5, 2003.

[76] I. H. Kim, J.-H. Choi, J. O. Joo, Y.-K. Kim, J.-W. Choi, and B.-K. Oh, "Development of a microbe-zeolite carrier for the effective elimination of heavy metals from seawater," Journal of Microbiology and Biotechnology, vol. 25, no. 9, pp. 1542-1546, 2015.

[77] S. Neha, V. Tuhina, and G. Rajeeva, "Detoxification of hexavalent chromium by an indigenous facultative anaerobic Bacillus cereus strain isolated from tannery effluent," African Journal of Biotechnology, vol. 12, no. 10, 2013.

[78] S. Srivastava, S. B. Agrawal, and M. K. Mondal, "A review on progress of heavy metal removal using adsorbents of microbial and plant origin," Environmental Science and Pollution Research, vol. 22, no. 20, pp. 15386-15415, 2015.

[79] J. L. Wang and C. Chen, "Biosorbents for heavy metals removal and their future," Biotechnology Advances, vol. 27, no. 2, pp. 195226, 2009.

[80] A. Bhattacharya, A. Gupta, A. Kaur, and D. Malik, "Efficacy of Acinetobacter sp. B9 for simultaneous removal of phenol and hexavalent chromium from co-contaminated system," Applied Microbiology and Biotechnology, vol. 98, no. 23, pp. 9829-9841, 2014.

[81] R. Zhao, B. Wang, Q. T. Cai et al., "Bioremediation of hexavalent chromium pollution by sporosarcina saromensis m52 isolated from offshore sediments in Xiamen, China," Biomedical and Environmental Sciences, vol. 29, no. 2, pp. 127-136, 2016.

[82] A. K. Nayan, S. S. Panda, A. Basu, and N. K. Dhal, "Enhancement of toxic $\mathrm{Cr}(\mathrm{VI})$, Fe, and other heavy metals phytoremediation by the synergistic combination of native Bacillus cereus strain and veltiveria of phytoremediation," Journal of Phytoremediation, vol. 20, no. 7, pp. 682-691, 2018. 
[83] C. K. Manoj, "Studies on Chromate Removal by ChromiumResistant Bacillus sp. isolated from Tannery Effluent," Journal of Environmental Protection, vol. 2, no. 1, pp. 76-82, 2011.

[84] O. M. Ontañon, M. Fernandez, E. Agostini, and P. S. González, "Identification of the main mechanisms involved in the tolerance and bioremediation of Cr(VI) by Bacillus sp. SFC 500-1E," Environmental Science and Pollution Research, vol. 25, no. 16, pp. 16111-16120, 2018.

[85] R. Kumar, D. Bhatia, R. Singh, S. Rani, and N. R. Bishnoi, "Sorption of heavy metals from electroplating effluent using immobilized biomass Trichoderma viride in a continuous packed-bed column," International Biodeterioration \& Biodegradation, vol. 65, no. 8, pp. 1133-1139, 2011.

[86] S. Sharma and A. Adholeya, "Hexavalent chromium reduction in tannery effluent by bacterial species isolated from tannery effluent contaminated soil," Journal of Environmental Science and Technology, vol. 5, no. 3, pp. 142-154, 2012.

[87] S. Congeevaram, S. Dhanarani, J. Park, M. Dexilin, and K. Thamaraiselvi, "Biosorption of chromium and nickel by heavy metal resistant fungal and bacterial isolates," Journal of Hazardous Materials, vol. 146, no. 1-2, pp. 270-277, 2007.

[88] A. Bhattacharya, A. Gupta, A. Kaur, and D. Malik, "Simultaneous bioremediation of phenol and $\mathrm{Cr}$ (VI) from tannery wastewater using bacterial consortium," International Journal of Applied Sciences and Biotechnology, vol. 3, no. 1, pp. 50-55, 2015.

[89] A. Bhattacharya and A. Gupta, "Evaluation of Acinetobacter sp. B9 for Cr (VI) resistance and detoxification with potential application in bioremediation of heavy-metals-rich industrial wastewater," Environmental Science and Pollution Research, vol. 20, no. 9, pp. 6628-6637, 2013.

[90] Z. A. Zakaria, Z. Zakaria, S. Surif, and W. A. Ahmad, "Hexavalent chromium reduction by Acinetobacter haemolyticus isolated from heavy-metal contaminated wastewater," Journal of Hazardous Materials, vol. 146, no. 1-2, pp. 30-38, 2007.

[91] T. S. Indu and S. Shaili, "Bioremediation and bioconversion of chromium and pentachlorophenol in tannery effluent by microorganisms," International Journal of Technology, vol. 3, pp. 224-233, 2011.

[92] J. F. Benazir, R. Suganthi, D. Rajvel, M. P. Pooja, and B. Mathithumilan, "Bioremediation of chromium in tannery effluent by microbial consortia," African Journal of Biotechnology, vol. 9, no. 21, pp. 3140-3143, 2010.

[93] D. Gunasundari and K. Muthukumar, "Simultaneous Cr(VI) reduction and phenol degradation using Stenotrophomonas sp. isolated from tannery effluent contaminated soil," Environmental Science and Pollution Research, vol. 20, no. 9, pp. 6563-6573, 2013.

[94] R. N. Bharagava and S. Mishra, "Hexavalent chromium reduction potential of Cellulosimicrobium sp. isolated from common effluent treatment plant of tannery industries," Ecotoxicology and Environmental Safety, vol. 147, pp. 102-109, 2018.

[95] S.-Y. Kim, J.-H. Kim, C.-J. Kim, and D.-K. Oh, "Metal adsorption of the polysaccharide produced from Methylobacterium organophilum," Biotechnology Letters, vol. 18, no. 10, pp. 11611164, 1996.

[96] L. W. Marzan, M. Hossain, S. A. Mina, Y. Akter, and A. M. M. A. Chowdhury, "Isolation and biochemical characterization of heavy-metal resistant bacteria from tannery effluent in Chittagong city, Bangladesh: Bioremediation viewpoint," Egyptian Journal of Aquatic Research, vol. 43, no. 1, pp. 65-74, 2017.

[97] H. Salehizadeh and S. A. Shojaosadati, "Removal of metal ions from aqueous solution by polysaccharide produced from
Bacillus firmus," Water Research, vol. 37, no. 17, pp. 4231-4235, 2003.

[98] N. S. Kumaran, A. Sundaramanicam, and S. Bragadeeswaran, "Adsorption studies on heavy metals by isolated cyanobacterial strain (nostoc sp.) from uppanar estuarine water, southeast coast of India," Journal of Applied Sciences Research, vol. 7, no. 11, pp. 1609-1615, 2011.

[99] J. De, N. Ramaiah, and L. Vardanyan, "Detoxification of toxic heavy metals by marine bacteria highly resistant to mercury," Marine Biotechnology, vol. 10, no. 4, pp. 471-477, 2008.

[100] S. A. Jafari, S. Cheraghi, M. Mirbakhsh, R. Mirza, and A. Maryamabadi, "Employing response surface methodology for optimization of mercury bioremediation by Vibrio parahaemolyticus PG02 in coastal sediments of Bushehr, Iran," CLEAN - Soil, Air, Water, vol. 43, no. 1, pp. 118-126, 2015.

[101] T. M. Roane and L. I. Pepper, "Microorganisms and metal pollution," in Environmental Microbiology, R. M. Maier, I. L. Pepper, and C. B. Gerba, Eds., Academic Press, London, UK, 2000.

[102] S. M. Al-Garni, K. M. Ghanem, and A. S. Ibrahim, "Biosorption of mercury by capsulated and slime layerforming Gram -ve bacilli from an aqueous solution," African Journal of Biotechnology, vol. 9, no. 38, pp. 6413-6421, 2010.

[103] B. Muneer, M. J. Iqbal, F. R. Shakoori, and A. R. Shakoori, "Tolerance and biosorption of mercury by microbial consortia: potential use in bioremediation of wastewater," Pakistan Journal Of Zoology, vol. 45, no. 1, pp. 247-254, 2013.

[104] K. Saranya, A. Sundaramanickam, S. Shekhar, S. Swaminathan, and T. Balasubramanian, "Bioremediation of mercury by vibrio fluvialis screened from industrial effluents," BioMed Research International, vol. 2017, 2017.

[105] B. E. Taştan, S. Ertuğrul, and G. Dönmez, "Effective bioremoval of reactive dye and heavy metals by Aspergillus versicolor," Bioresource Technology, vol. 10, no. 3, pp. 870-876, 2010.

[106] V. Achal, D. Kumari, and X. Pan, "Bioremediation of chromium contaminated soil by a brown-rot fungus, Gloeophyllum sepiarium," Research Journal of Microbiology, vol. 6, no. 2, pp. 166-171, 2011.

[107] P. Ashokkumar, V. M. Loashini, and V. Bhavya, "Effect of pH, Temperature and biomass on biosorption of heavy metals by Sphaerotilus natans," International Journal of Microbiology and Mycology, vol. 6, no. 1, pp. 32-38, 2017.

[108] K. Parvathi, R. Nagendran, and R. Nareshkumar, "Effect of pH on chromium biosorption by chemically treated Saccharomyces cerevisiae," Journal of Scientific and Industrial Research, vol. 66, no. 8, pp. 675-679, 2007.

[109] M. Iqbal and R. G. J. Edyvean, "Biosorption of lead, copper and zinc ions on loofa sponge immobilized biomass of Phanerochaete chrysosporium," Minerals Engineering, vol. 17, no. 2, pp. 217-223, 2004.

[110] N. M. A. Javaid, K. U. R. Bajwa, and R. A. Manzoor, "Biosorption of heavy metals by pretreatment of biomass of Aspergillus niger," Pakistan Journal of Botany, vol. 43, no. 1, pp. 419-425, 2011.

[111] A. Magyarosy, R. Laidlaw, R. Kilaas, C. Echer, D. Clark, and J. Keasling, "Nickel accumulation and nickel oxalate precipitation by Aspergillus niger," Applied Microbiology and Biotechnology, vol. 59, no. 2-3, pp. 382-388, 2002.

[112] P. C. Mane and A. B. Bhosle, "Bioremoval of some metals by living algae spirogyra sp. and spirullina sp. from aqueous solution," International Journal of Environmental Research, vol. 6, no. 2, pp. 571-576, 2012. 
[113] M. E. Goher, A. M. A. El-Monem, A. M. Abdel-Satar, M. H. Ali, A.-E. M. Hussian, and A. Napiórkowska-Krzebietke, "Biosorption of some toxic metals from aqueous solution using nonliving algal cells of Chlorella vulgaris," Journal of Elementology, vol. 21, no. 3, pp. 703-714, 2016.

[114] L. W. Aung, N. N. Hlaing, and N. K. Aye, "Biosorption of lead $\left(\mathrm{Pb}^{2+}\right)$ by using Chlorella vulgaris," International Journal of Chemical, Environmental amd Biological Sciences, vol. 1, no. 2, pp. 2320-4087, 2013.

[115] S. C. Wong, X. D. Li, G. Zhang, S. H. Qi, and Y. S. Min, "Heavy metals in agricultural soils of the Pearl River Delta, South China," Environmental Pollution, vol. 119, no. 1, pp. 33-44, 2000 .

[116] H. Tan, J. T. Champion, J. F. Artiola, M. L. Brusseau, and R. M. Miller, "Complexation of cadmium by a rhamnolipid biosurfactant," Environmental Science \& Technology, vol. 28, no. 13, pp. 2402-2406, 1994.

[117] A. Z. Syed, R. Mohd, I. Norli, and R. F. Shakoori, "Electrochemistry and microbiology of microbial fuel cells treating marine sediments polluted with heavy metals," RSC Advances, vol. 8, no. 34, pp. 18800-18813, 2018.

[118] N. Singh, V. Tuhina, and G. Rajeeva, "Detoxification of hexavalent chromium by an indigenous facultative anaerobic Bacillus cereus strain isolated from tannery effluent," African Journal of Biotechnology, vol. 12, no. 10, pp. 1091-1103, 2013.

[119] K. A. Mosa, I. Saadoun, K. Kumar, M. Helmy, and O. P. Dhankher, "Potential biotechnological strategies for the cleanup of heavy metals and metalloids," Frontiers in Plant Science, vol. 7, 2016.

[120] P. Sannasi, J. Kader, B. S. Ismail, and S. Salmijah, "Sorption of $\mathrm{Cr}(\mathrm{VI}), \mathrm{Cu}(\mathrm{II})$ and $\mathrm{Pb}(\mathrm{II})$ by growing and non-growing cells of a bacterial consortium," Bioresource Technology, vol. 97, no. 5, pp. 740-747, 2006.

[121] J. Kader, P. Sannasi, O. Othman, B. S. Ismail, and S. Salmijaj, "Removal of $\mathrm{Cr}$ (VI) from aqueous solutions by growing and non-growing populations of environmental bacterial consortia," Global Journal of Environmental Resource, vol. 1, pp. 12-17, 2007.

[122] Z. M. Puyen, E. Villagrasa, J. Maldonado, E. Diestra, I. Esteve, and A. Solé, "Biosorption of lead and copper by heavy-metal tolerant Micrococcus luteus DE2008," Bioresource Technology, vol. 126, pp. 233-237, 2012.

[123] O. P. Abioye, O. A. Oyewole, S. B. Oyeleke, M. O. Adeyemi, and A. A. Orukotan, "Biosorption of lead, chromium and cadmium in tannery effluent using indigenous microorganisms," Brazilian Journal of Biological Sciences, vol. 5, no. 9, pp. 25-32, 2018.

[124] G. A. Ashruta, V. Nanoty, and U. Bhalekar, "Biosorption of heavy metals from aqueous solution using bacterial EPS," International Journal of Life Science, vol. 2, no. 3, pp. 373-377, 2014.

[125] Q. Y. Fu, S. Li, and Y. H. Zhu, "Biosorption of copper (II) from aqueous solution by mycelial pellets of Rhizopus oryzae," African Journal of Biotechnology, vol. 11, no. 6, pp. 1403-1411, 2012.

[126] T. Akar, S. Tunali, and I. Kiran, "Botrytis cinerea as a new fungal biosorbent for removal of $\mathrm{Pb}(\mathrm{II})$ from aqueous solutions," Biochemical Engineering Journal, vol. 25, no. 3, pp. 227-235, 2005.

[127] A. Y. Dursun, G. Uslu, Y. Cuci, and Z. Aksu, "Bioaccumulation of copper(II), lead(II) and chromium(VI) by growing Aspergillus niger," Process Biochemistry, vol. 38, no. 12, pp. 1647-1651, 2003.
[128] S. Tiwari, S. N. Singh, and S. K. Garg, "Microbially enhanced phytoextraction of heavy-metal fly-ash amended soil," Communications in Soil Science and Plant Analysis, vol. 44, no. 21, pp. 3161-3176, 2013.

[129] R. M. Karakagh, M. Chorom, H. Motamedi, Y. K. Kalkhajeh, and S. Oustan, "Biosorption of $\mathrm{Cd}$ and $\mathrm{Ni}$ by inactivated bacteria isolated from agricultural soil treated with sewage sludge," Ecohydrology \& Hydrobiology, vol. 12, no. 3, pp. 191-198, 2012.

[130] P. S. Vankar and D. Bajpai, "Phyto-remediation of chrome-VI of tannery effluent by Trichoderma species," Desalination, vol. 222, no. 1-3, pp. 255-262, 2008.

[131] S. Srivastava and I. S. Thakur, "Isolation and process parameter optimization of Aspergillus sp. for removal of chromium from tannery effluent," Bioresource Technology, vol. 97, no. 10, pp. 1167-1173, 2006.

[132] K. Lakkireddy and U. Kües, "Bulk isolation of basidiospores from wild mushrooms by electrostatic attraction with low risk of microbial contaminations," AMB Express, vol. 7, no. 1, p. 28, 2017.

[133] D. Park, Y.-S. Yun, J. H. Jo, and J. M. Park, "Mechanism of hexavalent chromium removal by dead fungal biomass of Aspergillus niger," Water Research, vol. 39, no. 4, pp. 533-540, 2005.

[134] J. M. Luna, R. D. Rufino, and L. A. Sarubbo, "Biosurfactant from Candida sphaerica UCP0995 exhibiting heavy metal remediation properties," Process Safety and Environmental Protection, vol. 102, pp. 558-566, 2016.

[135] G. Dönmez and Z. Aksu, "Bioaccumulation of copper(ii) and nickel(ii) by the non-adapted and adapted growing Candida SP," Water Research, vol. 35, no. 6, pp. 1425-1434, 2001.

[136] C. N. Mulligan, R. N. Yong, and B. F. Gibbs, "Remediation technologies for metal-contaminated soils and groundwater: an evaluation," Engineering Geology, vol. 60, no. 1-4, pp. 193-207, 2001.

[137] S. Chatterjee, C. N. Chatterjee, and S. Dutta, "Bioreduction of chromium (VI) to chromium (III) by a novel yeast strain Rhodotorula mucilaginosa (MTCC9315)," African Journal of Biotechnology, vol. 1, pp. 14920-14929, 2012.

[138] H. Ksheminska, D. Fedorovych, T. Honchar, M. Ivash, and M. Gonchar, "Yeast tolerance to chromium depends on extracellular chromate reduction and Cr(III) chelation," Food Technology and Biotechnology, vol. 46, no. 4, pp. 419-426, 2008.

[139] H. P. Ksheminska, T. M. Honchar, G. Z. Gayda, and M. V. Gonchar, "Extra-cellular chromate-reducing activity of the yeast cultures," Central European Journal of Biology, vol. 1, no. 1, pp. 137-149, 2006.

[140] S. Grujić, S. Vasić, I. Radojević, L. Čomić, and A. Ostojić, “Comparison of the Rhodotorula mucilaginosa biofilm and planktonic culture on heavy metal susceptibility and removal potential," Water, Air, and Soil Pollution, vol. 228, no. 2, p. 73, 2017.

[141] M. H. El-Masry, E. El-Bestawy, and N. I. El-Adl, "Bioremediation of vegetable oil and grease from polluted wastewater using a sand biofilm system," World Journal of Microbiology and Biotechnology, vol. 20, no. 6, pp. 551-557, 2004.

[142] M. Chabukdhara, S. K. Gupta, and M. Gogoi, "Phycoremediation of heavy metals coupled with generation of bioenergy," in Algal Biofuels, pp. 163-188, Springer, 2017.

[143] J. He and J. P. Chen, "A comprehensive review on biosorption of heavy metals by algal biomass: materials, performances, chemistry, and modeling simulation tools," Bioresource Technology, vol. 160, pp. 67-78, 2014. 
[144] S. Tiwari, A. Hasan, and L. M. Pandey, "A novel bio-sorbent comprising encapsulated Agrobacterium fabrum (SLAJ731) and iron oxide nanoparticles for removal of crude oil co-contaminant, lead $\mathrm{Pb}(\mathrm{II})$," Journal of Environmental Chemical Engineering (JECE), vol. 5, no. 1, pp. 442-452, 2017.

[145] T. M. Frederick, E. A. Taylor, J. L. Willis, M. S. Shultz, and P. J. Woodruff, "Chromate reduction is expedited by bacteria engineered to produce the compatible solute trehalose," Biotechnology Letters, vol. 35, no. 8, pp. 1291-1296, 2013.

[146] A. Ibuot, A. P. Dean, O. A. McIntosh, and J. K. Pittman, "Metal bioremediation by CrMTP4 over-expressing Chlamydomonas reinhardtii in comparison to natural wastewatertolerant microalgae strains," Algal Research, vol. 24, pp. 89-96, 2017.

[147] J. Kostal, R. Yang, C. H. Wu, A. Mulchandani, and W. Chen, "Enhanced arsenic accumulation in engineered bacterial cells expressing ArsR," Applied and Environmental Microbiology, vol. 70, no. 8, pp. 4582-4587, 2004.

[148] S. Vinopal, T. Ruml, and P. Kotrba, "Biosorption of $\mathrm{Cd}^{2+}$ and $\mathrm{Zn}^{2+}$ by cell surface-engineered Saccharomyces cerevisiae," International Biodeterioration and Biodegradation, vol. 60, no. 2, pp. 97-102, 2007.

[149] L. M. Mateos, A. F. Villadangos, A. G. de la Rubia et al., "The arsenic detoxification system in corynebacteria: basis and application for bioremediation and redox control," Advances in Applied Microbiology, vol. 99, pp. 103-137, 2017. 

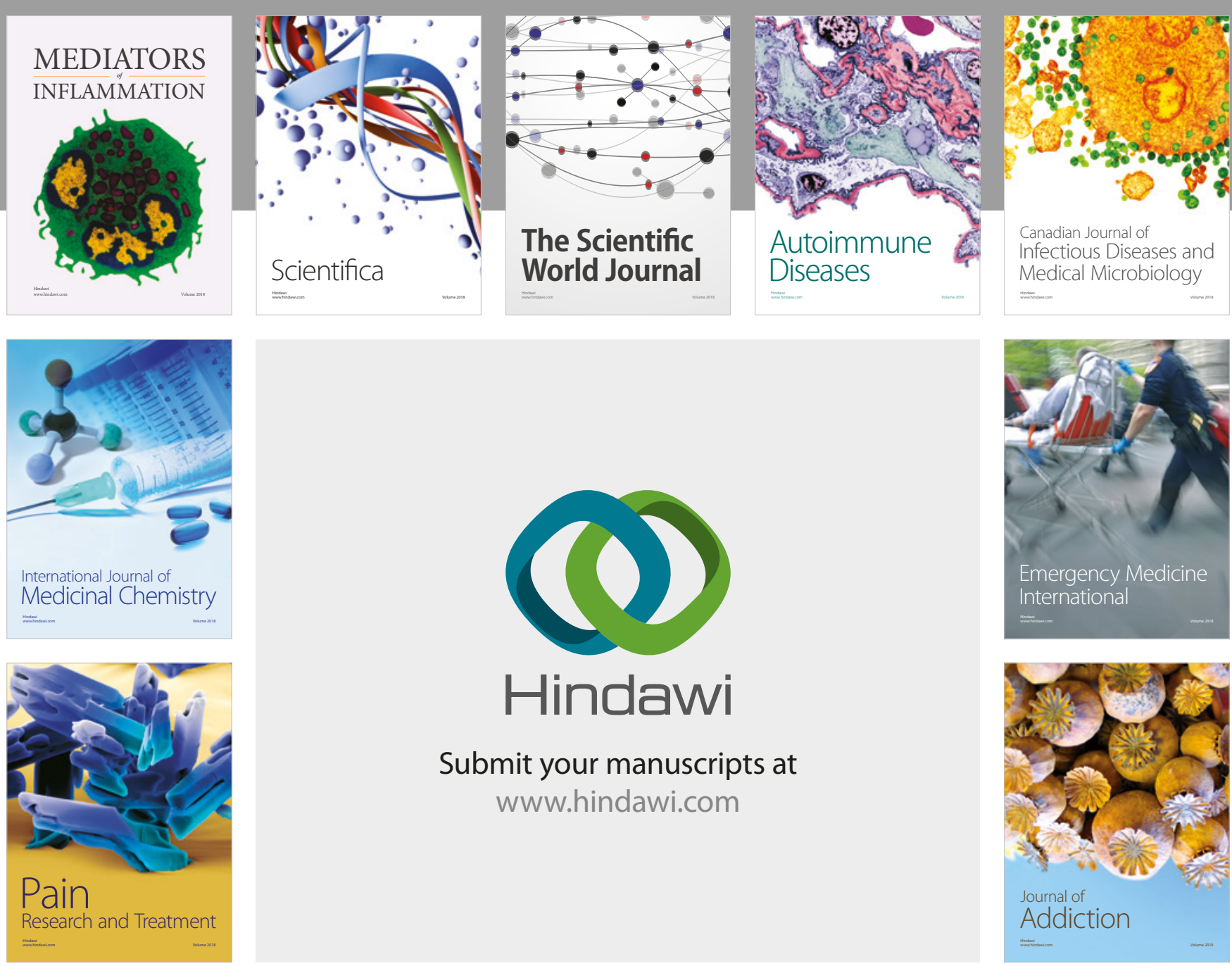

Canadian Journal of
Infectious Diseases and Medical Microbiology

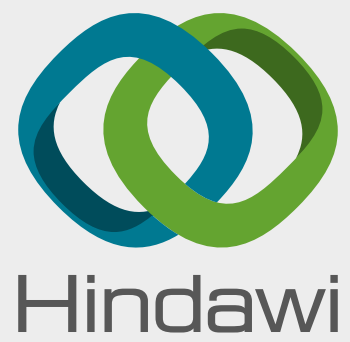

Submit your manuscripts at

www.hindawi.com
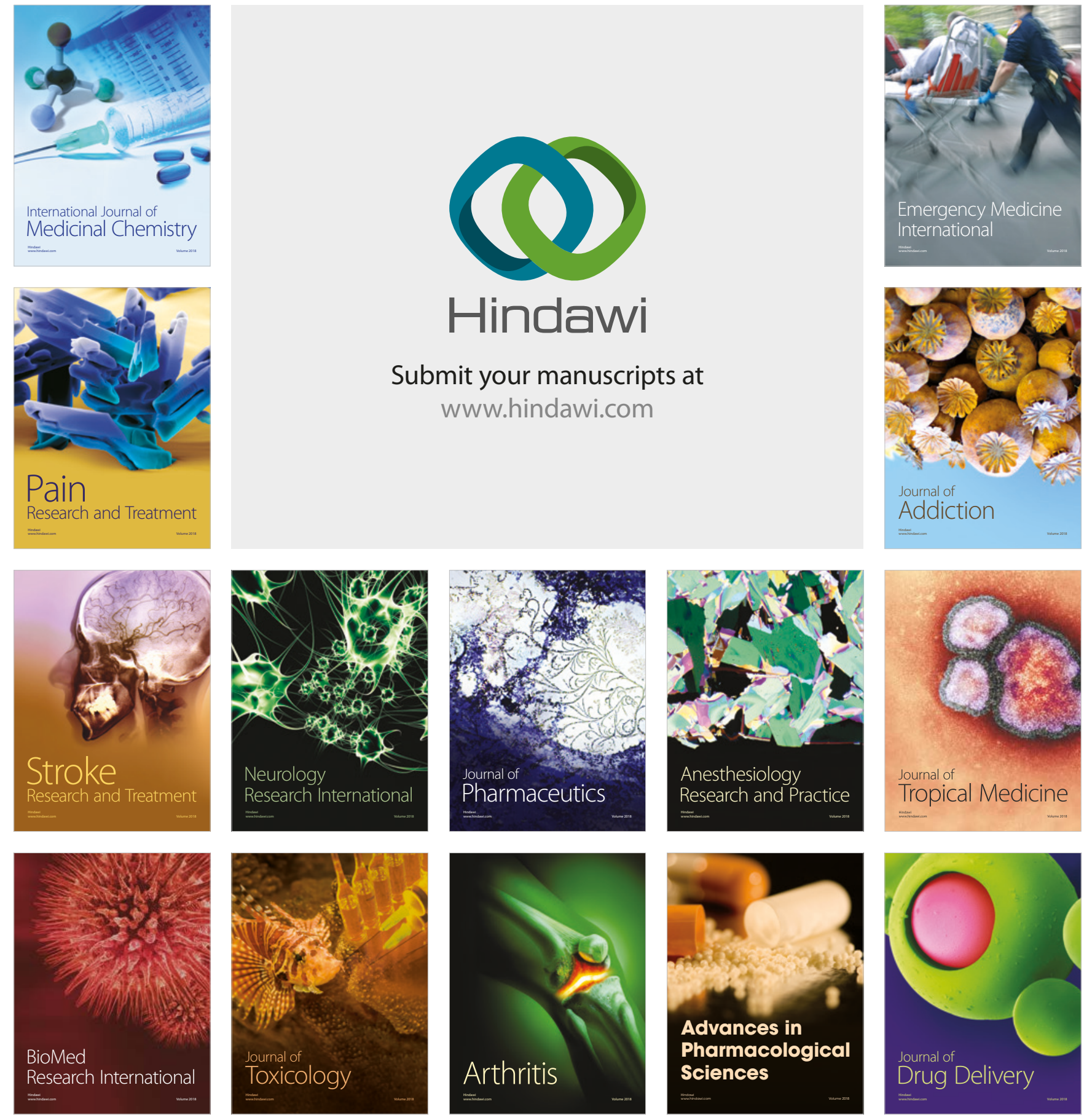